\title{
'Just as good a place to publish': Banksy, Graffiti and the Textualisation of the Wall
}

\author{
Anindya Raychaudhuri \\ Cardiff University, UK
}

\begin{abstract}
The article focuses on the work of the (in)famous graffiti artist Banksy, as a way into discussing the wider artistic and textual aspects of graffiti-art. Banksy has famously declared that the wall is 'just as good a place to publish' - a statement that certainly invites a study of graffiti-art as a movement to appropriate both the wall and the surrounding cityscape as a space to situate the 'texts'. A graffiti-artist has to remain, to use Baudelaire's expression, incognito, and the implications of a necessarily anonymous artist on both the nature and ownership of the 'text' created have to be considered when examining graffiti art. The transient and ephemeral nature that Baudelaire attributes to modernity constitutes the very essence of graffiti. Indeed, graffiti-art is doubly ephemeral - because the authorities 'buff' (remove) it with depressing regularity, and because its roadside existence means that the viewers themselves are usually in motion relative to the artwork. Graffiti artists like Banksy, therefore exemplify sociological criticism of early cinema (Georg Simmel's "Metropolis and Mental Life", for example.) and as such, should be an essential part of 'urban studies' of art and aesthetics.
\end{abstract}

[Keywords: Banksy, Graffiti, Art, Aesthetics, Politics, Urban]

Concepts like 'text', 'author', or even 'art' are totally alien to the world of graffiti-art, and thus always appear incongruous when used to analyse it. Graffitiart is (still) illegal, and the anonymous authors are felons who would presumably be prosecuted if caught. This makes it all the more important that we recognise the distinctive nature of graffiti-art when discussing it. Whenever one discusses a text, one has to use certain signifiers (title, author, publisher etc.) which either do not apply to graffiti-art at all, or when they do, apply in a substantially different manner. Graffiti art might share some features with more conventional artistic genres but it is, in the end, a unique textual category and needs to be analysed as such.

As the most famous British graffiti-artist, Banksy enjoys a unique level of prominence - the BBC has profiled his work on its flagship cultural programme The Culture Show ${ }^{1}$, while newspapers like The Guardian and The New York Times regularly feature interviews and articles both by and about him. The latest issue of the glossy magazine GQ features a long article about the artist and his work. He has published books, organised both legitimate and illegal exhibitions, and his gestures like placing 'fake' artwork in the Museum of Modern Art in New York, painting on the Israel-Palestine wall, and doctoring music records by celebrity Paris Hilton have made the headlines on both sides of the Atlantic. Banksy's art-work is now featured in mainstream art-galleries and auction houses like Sotheby's sell his work for hundreds of thousands of pounds. On one level, this level of popularity has made critical analysis of both his work and the genre itself both easier and more legitimate. Books and exhibitions provide a degree of permanence which facilitates serious academic discourse of what is essentially a transient art form. On another level, however, we should be aware of the risks of transforming what is a unique artform to a more mainstream format in order to

\footnotetext{
Rupkatha Journal on Interdisciplinary Studies in Humanities

Volume 2, Number 1, Special Issue, Visual Arts

URL of the Issue: http://rupkatha.com/rupkathav2n1.php

PDF URL of the article:

http://rupkatha.com/V2/n1/BanksyGraffitiArt.pdf

(C) www.rupkatha.com
} 
better fit the framework of the critical industry. As an artist who today is equally comfortable on the streets and in art galleries, who 'sells' us his work on both the walls of our cities and in hardback books in our bookshops, Banksy provides a very interesting route into analysing the uniqueness of graffiti-art, and its relationship with the mainstream art world which it might ridicule and even despise, but cannot do without. In the words of Lauren Collins in the aforementioned $G Q$ article: 'Banksy, typically, was giving the finger to the art world and begging it to notice him at the same time. ${ }^{2}$

The act of producing and viewing a piece of graffiti-art is essentially different from that of mainstream art. In fact, Banksy is deliberately trying to create a different form of art and, indeed, a different variety of 'text' through his artwork: 'The word has a lot of negative connotations and it alienates people, so no, I don't like to use the word "art" at all.'3 By actively seeking new spaces for, and forms of art, Banksy and other graffiti-artists are attempting to posit their own version of the infrastructure surrounding mainstream art, which is a world they feel themselves alienated from. As a result, graffiti-art should be seen not just a different art form but as a different and unique category of "text".

Graffiti-art provides the ultimate expression of what Simmel called 'the metropolitan individuality', a consciousness that is shaped by, and which depends on 'the swift and continuous shift of external and internal stimuli' ${ }^{4}$. If Baudelaire was right to define modernity as 'the ephemeral, the fugitive, the contingent' ${ }^{5}$ then it follows that graffiti-art is ultimately modern, because the very nature of such art is inextricably linked to its transience. Graffiti-art is, in fact, doubly transient - because of its illegality it is 'buffed' (removed) by the authorities with depressing regularity, but also because of its almost overwhelmingly urban roots, the audience is in constant motion, and, therefore, their response is limited by the short amount of time before the train or bus starts moving again. Graffiti-art becomes another stimulus within the wider urban experience. For the twenty-first century equivalent of Baudelaire's flâneur, the work of artists like Banksy is an inescapable part of the contemporary urban experience. As such it is perfectly appropriate that Banksy has attracted a cult following, with enthusiasts forced to venture out onto the streets in search of his work:

It is easy to become addicted to his work. Since spotting my first few Banksies, I have been desperately seeking out more. When I do come across them, surreptitiously peeping out of an alley or boldly emblazoned on a wall, I find it hard to contain myself. They feel personal, as if they are just for me, and they feel public as if they are a gift for everyone. They make me smile and feel optimistic about the possibilities of shared dreams and common ownership. ${ }^{6}$

Given graffiti-art's ultimate transience, it is not surprising that Banksy is so deeply interested in those two other fundamentally transient (Modern) forms of art - the cinema and the Internet. Banksy has repeatedly declared his fascination with the cinema 'as the only art form, apart from graffiti, that matters. ${ }^{7}$ The influence of cinema on Banksy's work can be seen from such pieces as 'Pulp Fiction', where he draws on the work of acclaimed director Quentin Tarrantino. Similarly, Banksy attributes the overrepresentation of graffiti on the Internet to the fact that the web... perfectly reflects its transient nature ${ }^{, 8}$ 
One of the most interesting characteristics of this distinctive textual variety is the interplay between the written word and the visual image. Graffiti-art is one of the very few genres in which the written word itself becomes a visual image. When Roland Barthes analyses a picture in a newspaper, he notes how the picture and the caption, though working together, form two entirely separate structures:

These two structures are co-operative but, since their units are heterogeneous, necessarily remain separate from one another: here (in the text) the substance of the message is made up of words; there (in the photograph) of lines, surfaces, shades. Moreover, the two structures of the message each occupy their own defined spaces...9

For Barthes, the photograph and the caption/commentary that goes with it are "in communication with" each other and "although a press photograph is never without a written commentary", these units remain distinct and any "analysis must first of all bear on each separate structure; it is only when the study of each structure has been exhausted that it will be possible to understand the manner in which they complement one another." ${ }^{\prime 0}$ The visual image and the written word depend on each other in order to convey their message, but unless each is analysed as a semantically and spatially distinct unit, this message will not be understood.

For our present purposes, it is enough to note that Barthes' analysis illustrates the almost oppressively maintained divergence of the written word and the visual image within both conventional art and its critical discourse. This duality is one of the many conventions of mainstream art that graffiti seeks to undermine. Thus, when graffiti-artists cover a particular wall with colourful and elaborate 'tagging' (also known as agnomena or writing one's name on walls) they are, in fact, achieving this effect. The audience not only reads the text that has been written onto the wall, but they also notice the deliberate patterns of colour that constitute the letters. Barthes' distinction between "letters" and "lines, surfaces, shades" just does not apply here; they are one and the same.

In one of the many subways around Marble Arch in Central London, Banksy stencilled, within the focus of a CCTV camera, the words "What Are You Looking At?"11 in an austere, black font. This piece perfectly illustrates the fusion of the written word and the visual image because it, in effect, answers its question itself; the black lines that form the words themselves constitute both the words and the visual image that the audience (and the camera) focuses on.

Even in graphic novels, perhaps the genre where the word and the image come closest to unification, they remain essentially distinct, both spatially and in terms of the narrative. Graphic-novels can thus have two distinct narratives, one illustrated through the pictures, the other through the written word. It is only in graffiti-art, however, that these apparently heterogeneous structures are fused, and the words that make up the text are as important as the lines that make up the letters. An indication of how completely these structures have fused is the fact that the terms graffiti-artist and graffiti-writer are used interchangeably in the literature of the genre. Indeed, Banksy always refers to himself as a graffiti-writer, as do most other artists/writers of the genre. This shows that conventional genre boundaries between the word and the image do not apply when studying (or indeed producing) graffiti-art. 
Apart from the obvious artistic implications, there are also some equally crucial political connotations to this fusion of the written word and the visual image. Just as the words 'writer' and 'artist' indicate apparently separate fields of work, so do the words 'reader' and 'audience'. This is because the written word is essentially private since the act of reading is a solitary one, while the visual image is a public object since the act of looking at a picture is a public, collective one. By saying that we 'look at' as well as 'read' Banksy's words, we are saying that he is fusing not just the word and the image but also the private and the public. Just as Banksy is both 'writer' and 'artist', we are both reader and audience of his work; we are both individual and collective.

Given that, by its very nature, graffiti-art seeks to undermine the private/public duality, it is perfectly appropriate that Banksy posits graffiti as a tool to fight against what he sees as the usurping of our public spaces by corporations and their advertising hoardings. For Banksy, graffiti-artists are in the business of returning public spaces to public ownership:

Any advert in public space that gives you no choice whether you see it or not is yours...You can do whatever you like with it. Asking for permission is like asking to keep a rock someone just threw at your head... They have re-arranged the world to put themselves in front of you. They never asked for your permission, don't even start asking for theirs. ${ }^{12}$

Banksy illustrates this perfectly by his work entitled "McDonalds is stealing our children". He ties a blow-up doll to a red balloon with the golden arches of the McDonald's logo, thus, implicitly highlighting the difference in reception of the same sign depending on who 'owns' it. As a corporation, McDonald's can buy out a space within the city and advertise themselves in it. If a graffiti-artist places the same symbol in the same space, he is committing a crime because the 'public' space of the city has, in effect, been privatised by a corporation. Banksy's work is seen as threatening because it challenges the notion that public spaces can be bought and owned by private interests.

What the authorities find so dangerous is what, according to Banksy, gives his work a level of honesty that commercial art can never achieve:

Graffiti is not the lowest form of art. Despite having to creep about at night and lie to your mum it's actually the most honest artform available. There is no elitism or hype, it exhibits on some of the best walls a town has to offer, and nobody is put off by the price of admission. ${ }^{13}$

Banksy is scathing about the elitism that he associates with mainstream art, something which, he believes, leaves us inevitably disenfranchised from the art that we see:

The Art we look at is made by only a select few. A small group create, promote, purchase, exhibit and decide the success of Art. Only a few hundred people in the world have any real say. When you go to an art gallery you are simply a tourist looking at the trophy cabinet of a few millionaires. ${ }^{14}$

Because of the economic position of most of us in society, we are denied access to the elite coterie that decides on the nature of art in our society. As such, Banksy argues, we have very little alternative than to occupy the spaces that we can gain access to (i.e. walls) and use them to make our voice heard. 
Graffiti writers do not challenge boundaries just to destroy the dichotomy between public and private. When Banksy paints a tropical beach on the IsraelPalestine wall, he is obviously making a deliberate political statement about the legitimacy of the wall itself:

Palestine has been occupied by the Israeli army since 1967. In 2002 the Israeli government began building a wall separating the occupied territories from Israel, much of it illegal under international law. It is controlled by a series of checkpoints and observation towers, stands three times the height of the Berlin wall and will eventually run for over $700 \mathrm{~km}$ - the distance from London to Zurich. Palestine is now the world's largest open-air prison and the ultimate activity holiday destination for graffiti artists. ${ }^{15}$

The same effect is achieved by the simpler, if equally haunting, drawing of a ladder along the height of the wall. By highlighting the powerlessness of the Palestinian people to overcome the wall, Banksy is questioning the authority of both the wall and the state which erected it. Painting from the Palestinian side of the 'Israeli' wall, Banksy is also undermining the apparent Israeli ownership of the wall.

Banksy's work on the Israeli wall highlights the often strange relationship between a graffiti-artist and his canvas. As we have seen above, by painting on the wall Banksy is, on one level, undermining both the Israeli claim on the ownership of the wall but also the very legitimicay of the wall in the first place. The paradox, however, is that graffiti art needs such walls and boundaries to exist in the first place. Banksy sees as a wall as a blank canvas that he can use to get his views across: 'A musician might look at a blank piece of paper and see a symphony on it...I see a wall and see nothing but possibilities. It's like running around with permanent cross hairs on your eyes. ${ }^{16}$ As the last image indicates, Banksy treats a wall not just as a canvas but as an integral tool in his artistic warfare: '...the wall is the weapon of choice to hit...back ${ }^{17}$ Banksy almost equates the wall with the weapons brandished by the military forces that defend the system he is fighting against: 'A wall is a very big weapon. It is one of the nastiest things you can hit someone with. ${ }^{18}$ Just as an intrinsic aspect of graffiti is its illegal nature and its constant battle with the authorities, its existence necessitates the very walls it seeks to undermine. By writing or painting on a wall, therefore, the graffiti-artist is drawing attention to the wall as a physical entity attempting at the same time to both transcend and reinforce the space that the wall encloses.

This is the source of the inherently radical nature of graffiti. When a writer scrawls his name on a wall, he is claiming ownership not only of the wall, but of the physical space surrounding the wall as well. In Banksy's words:

I try and deal with lots of different ideas but I guess the underlying message is always the same - You say the city belongs to you and your laws? Well then how come it's got MY name written all over it. ${ }^{19}$

The practice of tagging is clearly an example of the writer attempting to stake a claim on the 'public' landscape that he/she feels alienated from. Unlike conventional artists who 'own' their canvas before they start painting on it, graffitiartists lay claim to their canvas by the very act of painting/writing on it.

By fusing the private word and the public image, the artist is able to fuse the private canvas and the public wall, paradoxically making the public spaces in 
the city truly public. Banksy does this overtly by stencilling "This Wall is a Designated Graffiti Area" on different walls around London. The plethora of graffiti-art that follows this act demonstrates that, through his artwork Banksy is 'permitting' graffiti on a wall, by giving all those artists a voice that they previously had not had. Just as the consumers of graffiti-art are both individual and collective and just as graffiti-art is both word and image, the authorship of the 'work' is both individual and collective as well. There have been multiple authorial voices that have gone towards making what "This Wall is a Designated Graffiti Area" is, but the resulting work is emphatically 'a Banksy'.

It is crucial to remember that when Banksy is making the public wall truly public, he is doing so by transforming it into a text. To put it simply, Banksy and other graffiti-artists claim ownership over a wall not just economically but also artistically - not just as a piece of property (public or otherwise) but also as a canvas where art can legitimately be situated. In Banksy's words, "A musician might look at a blank piece of paper and see a symphony on it...I see a wall and I'll see nothing but possibilities." ${ }^{20}$ Of course, the wall is not the only alternative canvas that Banksy has used - he has also drawn on trains, cars, animals, liner notes for records by celebrity music stars, other people's paintings, and a whole host of other objects conventionally thought to be beyond the boundaries of art. Banksy has famously said that a wall 'is just as good a place to publish' - a statement that certainly invites a study of graffiti-art as a movement to appropriate both the wall and the surrounding cityscape as a space to situate the 'texts'. The Oxford English Dictionary defines the word 'publish' as 'To issue or cause to be issued for sale to the public (copies of a book, writing, engraving, piece of music, or the like); said of an author, editor, or spec. of a professional publisher. $^{21}$ The word then connotes an economic transaction involving an authoritative, usually permanent version of the text, between reader/audience/consumer and author/performer/producer. It is interesting that Banksy should use this term because graffiti-art obviously does not belong to the world of art as an economic commodity. Indeed, by its very nature, there seems something inescapably paradoxical about making something public by textualising it. A 'text' is, of course, anything but public as it is owned first by the artist, then by its consumer, who after all has to pay for the privilege.

This reflects a wider paradox surrounding the reproducibility of graffiti-art. Like any other art form, its efficacy depends on how many people have access to it, on how widely it is distributed. However, graffiti-art's essentially transient nature means it is very difficult to disseminate among a wide audience. Any critical analysis of graffiti-art (like this one), then, depends on the piece of artwork been reproduced onto a page. As we have seen before, however, graffiti-art needs to be in the public space to achieve any political force. In this case, analysis of the art directly leads to it being neutered. In the words of Walter Benjamin:

Even the most perfect reproduction of a work of art is lacking in one element: its presence in time and space, its unique existence at the place where it happens to be... The presence of the original is the prerequisite to the concept of authenticity... The situations into which the product of mechanical reproduction can be brought may not touch the actual work of art, yet the quality of its presence is always depreciated...that which withers in the age of mechanical reproduction is the aura of the work of art. ${ }^{22}$ 
Interestingly, however, it is not the mere act of reproduction that strips graffiti-art of its power. After all, stencilling (the method favoured by Banksy) is desirable precisely because of ease of reproduction. By cutting down on the time it takes to execute an artwork, Banksy manages to minimise the chances of being caught in the act. Also, reproducing the same artwork on more than one wall only reinforces its effect. The second it is transferred from the wall (where it is not allowed to exist) to a canvas/page (where it gains official legitimacy) it stops being graffiti and becomes mainstream art. When Banksy prints his stencils in a book, or organises exhibitions of his work, he stops becoming a graffiti-artist and becomes a conventional artist.

This hides a more fundamental paradox regarding the illegal nature of graffiti-art. Banksy often displays a romantic notion of a world where graffiti was legal:

Imagine a city where graffiti wasn't illegal, a city where everybody could draw wherever they liked. Where every street was awash with a million colours and little phrases. Where standing at a bus stop was never boring. A city that felt like a party where everyone was invited. Not just the estate agents and barons of big business. Imagine a city like that and stop leaning against the wall - it's wet. $^{23}$

However, Graffiti-art gains its aura (to use Benjamin's term) precisely from being somewhere it is not allowed to be, and therefore, can maintain an authentic presence for only as long as the authorities take to remove it. In Banksy's own words, when he moves his art work from the streets to an art-gallery, or the pages of a book, his work ceases to be 'the most honest artform available' because people can now be 'put off by the price of admission'. ${ }^{24}$ By reproducing his artwork, Banksy effectively castrates it, leaving it powerless. Once graffiti deserts the streets, it is subsumed in the world of mainstream art - and as such, can be analysed, criticised and packaged as a product precisely because it is no longer a threat.

However, it is all too easy to accuse someone like Banksy of 'going commercial' and betraying his roots. One would do well to remember that graffitiartists who wish to make a statement are in a very difficult situation. Like any artist, they want their work to be seen and discussed by a large audience, but unless they make that journey from the wall to the page, they are limited by the same transience that gave their work its power in the first place. This is further emphasised by Banksy himself, who is perfectly aware of what he loses by making this transition: '...l've done gallery shows and if you've been hitting on people with all sorts of images in all sorts of places, they're a real step backwards. Painting the streets means becoming an actual part of the city. It's not a spectator sport. ${ }^{25}$ Even while he organises exhibitions, designs album covers and publishes books, Banksy always maintains the artistic supremacy of graffiti: 'The only thing that depresses me about graffiti is that pretty much any other art form...is a step down from here. I don't ever want to stop. ${ }^{26}$ There is undeniably a paradox surrounding Banksy's move from graffiti to conventional art, but his statements surrounding this move indicate that it does not necessarily represent selling out. As he puts it in his interview with Lauren Collins:

The money...makes me feel uncomfortable, but...you just stop winging and give it all away. I don't think it's possible to make art about world poverty and then trouser all the cash, that's an irony 
too far, even for me...l love the way capitalism finds a place even for its enemies. It's definitely boom time in the discontent industry. ${ }^{27}$

In our study of graffiti, we must be careful not to just 'find a place' for him. We cannot afford to limit our study of graffiti-art to transforming (neutering) graffiti-art into mainstream art. Graffiti-art is important because it does not follow the rules, does not permit commoditization, does not involve the cult of the author or the sanctity of the text that it can straddle boundaries like public/private or word/image. It is always there, in the margins, threatening the centre but rarely ever invading it. It demands that we discard our ways of thinking, and interact with it on its own terms, where 'author', 'text', 'image' or 'art' either do not apply or mean something radically different. As students of graffiti-art, we need to develop new techniques of reading the texts. Unlike mainstream art, we cannot open a book or visit a gallery - there is no distinct forum within which the text can be safely contained. As we adapt our methods of 'reading' this new kind of text, we also have to adapt our existing terminology, or create new terms to better describe what we see. Unless we can do this, we are fated to miss the textual, aesthetic and political significance of both graffiti-art and graffiti artists.

\section{Books and Articles}

\section{Bibliography}

- Banksy, Wall and Piece London: Century, 2005

- Barthes, R., "The Photographic Image" in Image Music Text [Trans. Stephen Heath] London: Fontana Press, 1977

- Benjamin, W., Illuminations [Trans. H. Zorn, Ed. H. Arendt] London: Pimlico, 1999

- Bowlby, R., 'Défense d'afficher: Posters, Women and Modernity' in Shopping: A Century of Art and Consumer Culture [Ed. Christoph Grunenberg and Max Hollein] Ostfilden-Ruit, Germany: Hatje Cantz Publishers, 2002

- Collins, L., 'Icon Banksy' in GQ, September 2007. pp 98-104

- Hattenstone, S. 'Something to Spray' in The Guardian, Thursday, July $17^{\text {th }}, 2003$

- Manco, T., Stencil Graffiti London: Thames \& Hudson, 2002

- Warren, E., 'Need to Know' in The Observer Magazine, Sunday, $26^{\text {th }}$ May, 2002

\section{Internet Resources}

- $\quad$ http://www.banksy.co.uk accessed on $14^{\text {th }}$ September, 2006

- http://www.designiskinky.net/profiles/banksy.html accessed on 14th September, 2006

- $\quad$ http://www.oed.com accessed on $14^{\text {th }}$ September, 2006

\section{End Notes}

\footnotetext{
${ }^{1}$ First aired on the $27^{\text {th }}$ of October at $7 \mathrm{pm}$ on BBC1

${ }^{2}$ Collins 101

${ }^{3}$ http://www.banksy.co.uk/help/index.html

${ }^{4}$ Simmel 325

${ }^{5}$ Baudelaire 13

${ }^{6}$ Hattenstone (2003)

${ }^{7}$ cited in Warren (2002)

${ }^{8}$ Banksy (2006)

${ }^{9}$ Barthes 'PM', 16

${ }^{10}$ Barthes 'PM', 16
} 
${ }^{11}$ Banksy 75

12 Banksy WP, 160

${ }^{13}$ ibid. 8

14 ibid. 144

${ }^{15}$ Banksy WP, 110

${ }^{16}$ cited in Warren (2002)

${ }^{17}$ Banksy WP, 8

${ }^{18}$ Banksy Banging, 26

${ }^{19} \mathrm{http}: / /$ www.designiskinky.net/profiles/banksy.html

${ }^{20}$ Warren (2002)

${ }^{21} \mathrm{http}: / /$ www.oed.com

${ }^{22}$ Benjamin 214-15

${ }^{23}$ ibid. 85

${ }^{24}$ Banksy WP, 8

${ }^{25}$ Cited in Manco SG, 79

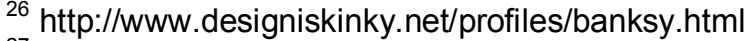

${ }^{27}$ Collins 104

Anindya Raychaudhuri is a $\mathrm{PhD}$ researcher at Centre for Critical and Cultural Theory, Cardiff University, UK. Email: raychaudhuria@cf.ac.uk 